\title{
Strangulated Morgagni hernia in an adult: Synchronous prolapse of the liver and transverse colon
}

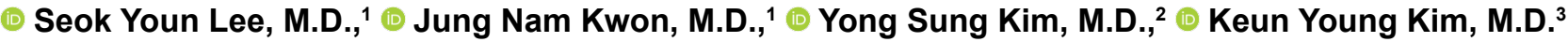

\author{
1'Department of Surgery, Wonkwang University Sanbon Hospital, Wonkwang University School of Medicine, Gunpo-Korea \\ ${ }^{2}$ Department of Internal Medicine, Wonkwang University Sanbon Hospital, Wonkwang University School of Medicine, Gunpo-Korea \\ ${ }^{3}$ Department of Surgery, Wonkwang University Hospital, Wonkwang University School of Medicine, Iksan-Korea
}

\begin{abstract}
Morgagni hernia $(\mathrm{MH})$ is a very rare congenital defect found in the anterior aspect of the diaphragm between the costal and sternal portions of the muscle. The most common defect is congenital diaphragmatic hernia, $90 \%$ of which are Bochdalek type. MHs account for approximately $3 \%$ of all diaphragmatic hernias. Most MHs are found and repaired in children, but $5 \%$ are found in adults. Here, we present the case of an incarcerated and strangulated $\mathrm{MH}$ with synchronous prolapse of the liver and transverse colon in a 77-year-old man who was admitted to our hospital for abdominal pain and symptoms of intestinal obstruction.
\end{abstract}

Keywords: Adult; Morgagni hernia; synchronous.

\section{INTRODUCTION}

$\mathrm{MH}$ was first described in 1769 by the Italian anatomist and pathologist Giovanni Battista Morgagni as an anterior diaphragmatic hernia originating from the costosternal trigones, a triangular space located between the muscle fibers originating from the xiphisternum and the costal margin of the diaphragm, and protruding into the central tendon. ${ }^{[I]}$ The most common contents of the hernia sac include the omentum, followed by the colon, small bowel, stomach, and portions of the liver. ${ }^{[2]}$ To our knowledge, the present case is a rare case of an adult with $\mathrm{MH}$ presenting with abdominal pain and synchronous prolapse of the liver and transverse colon.

\section{CASE REPORT}

A 77-year-old man was admitted to the emergency room of our hospital complaining of respiratory distress, upper abdominal pain, nausea, and intermittent vomiting for two days. His medical history included interstitial lung disease, for which he did not receive treatment. He had no history of past trauma or surgery. Physical examination revealed a soft abdomen with some tenderness in the epigastrium. Cardiopulmonary auscultation revealed decreased air entry in the right lung base but no other unusual findings. He was apyrexial and hemodynamically stable. Initial chest radiography revealed a soft-tissue mass and air-filled heterogeneous areas in the lower area of the right hemithorax (Fig. Ia). Computed tomography (CT) of the abdomen showed an intrathoracic transverse colon and liver at the right cardiodiaphragmatic angle (Fig. Ib). High-resolution computed tomography (HRCT) of the chest showed honeycombing consisting of multilayered thick-walled cysts in the basal and subpleural region (Fig. Ic). The patient was suspected to have $\mathrm{MH}$ with interstitial lung disease (usual interstital pneumonia pattern). Because he was considered not to have acute intestinal obstruction or strangulation, elective surgery was planned. However, $18 \mathrm{~h}$ after admission, the patient demonstrated progressive tachycardia and complained of increasing abdominal pain. CT of the abdomen revealed evidence of strangulated herniation of the transverse colon (Fig. 2).

\footnotetext{
Cite this article as: Lee SY, Kwon JN, Kim YS, Kim KY. Strangulated Morgagni hernia in an adult: Synchronous prolapse of the liver and transverse colon. Ulus Travma Acil Cerrahi Derg 2018;24:376-378.

Address for correspondence: Seok Youn Lee, M.D.

Wonkwang University Sanbon Hospital, Wonkwang University School of Medicine,

32I, Sanbon-ro, Gunpo-si, Gyeonggi-do, I5865, Korea, Gunpo-si-South Korea.

Tel: +82-3I-390-2218 E-mail: sylee3।4@hotmail.com

Ulus Travma Acil Cerrahi Derg 2018;24(4):376-378 DOI: 10.5505/tjtes.2017.99045 Submitted: 14.01.2017 Accepted: 21.12.2017 Online: 19.06.2018

Copyright 2018 Turkish Association of Trauma and Emergency Surgery
} 

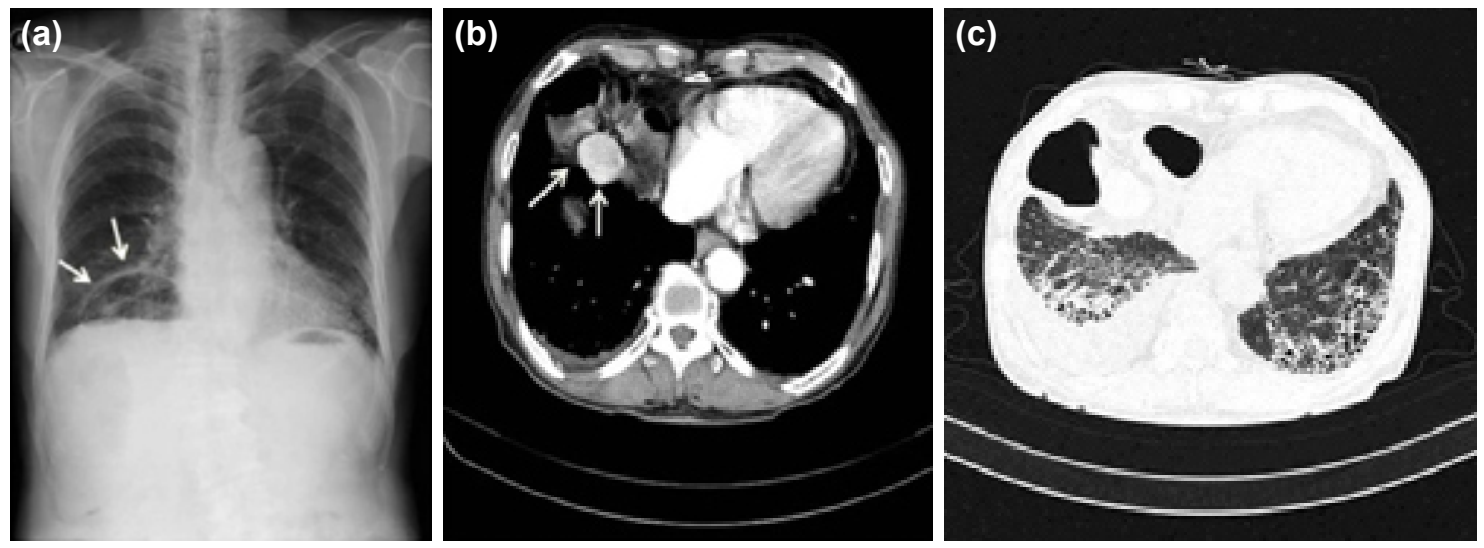

Figure 1. (a) Plain radiogram of the chest showing a soft tissue mass with air-fluid levels at the right cardiophrenic angle (white arrows); (b) Axial computed tomographic image of the abdomen, showing a right intrathoracic transverse colon and liver with cardiac deviation. A small pleural effusion also can be seen (white arrows = liver); (c) High-resolution computed tomographic image of the chest showing honeycombing comprising reticular densities caused by thick walls of cysts as well as architectural distortion with traction bronchiectasis because of fibrosis.

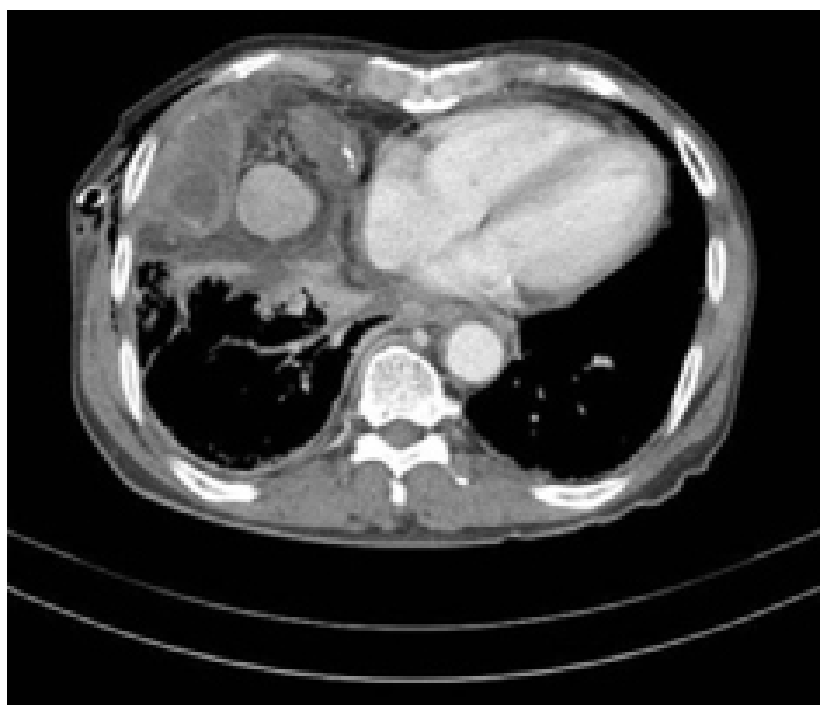

Figure 2. Axial computed tomographic image, showing a Morgagni hernia with strangulation of the transverse colon and liver; Fluid accumulation is noted at the superior aspect of the hernia with collapse of the underlying lung.
Emergency laparotomy was performed, with the herniated liver and transverse colon reduced into the abdomen. The transverse colon and omentum demonstrated necrotic changes (Fig. 3a and b). Resection of $20 \mathrm{~cm}$ of the transverse colon and partial omentectomy were performed with endto-end hand-sewn anastomosis. Copious laparoscopic-guided lavage of the right hemithorax also was performed using $0.9 \%$ normal saline (Fig. 3c and d). The diaphragmatic defect was closed using 2-0 prolene with interrupted vertical mattress sutures. Prior to closure, a 32-F chest drain was inserted into the right intercostal space in the axillary line. The patient had uneventful postoperative recovery and remains well.

\section{DISCUSSION}

$\mathrm{MH}$ is a relatively rare pathologic condition. It arises from a defect of the septum transversum caused by the failure of closure of the pars sternalis with the seventh costochondral arch. ${ }^{[3]} \mathrm{MHs}$ are far more common on the right side despite protection from the liver. The rare incidence of a left-sided diaphragmatic hernia can be explained by the formation of a
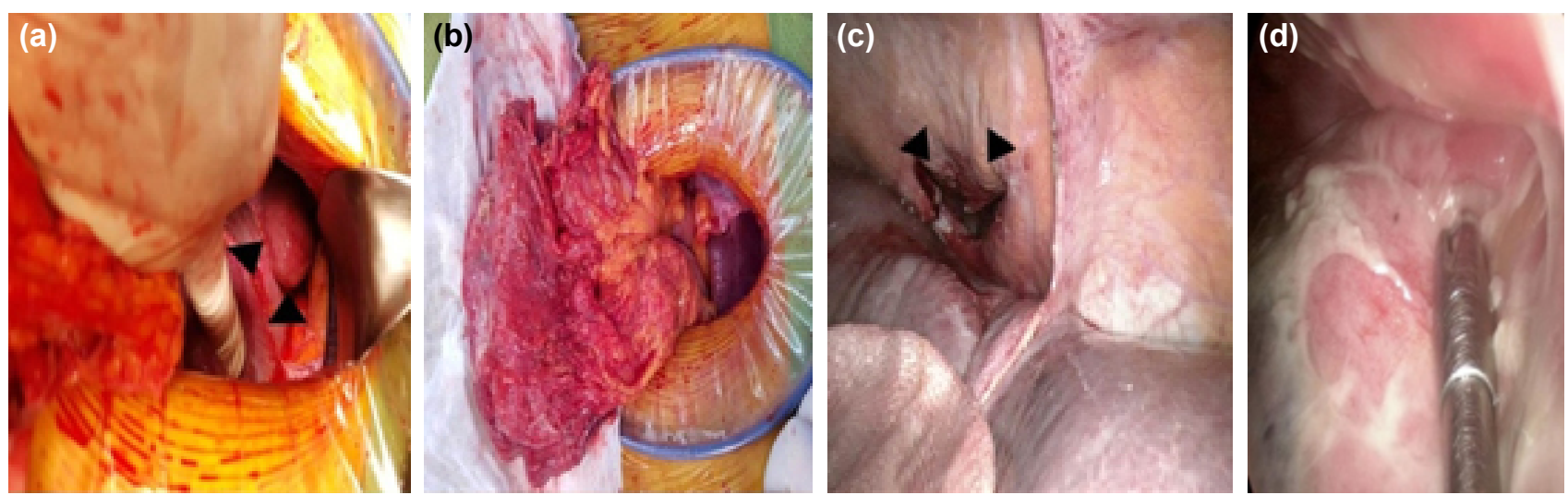

Figure 3. (a) Operative view of the herniated left liver lobe (medial superior area) (black arrowheads); (b) Operative findings included a small and covered perforation with necrosis at the antimesenteric site of the transverse colon; (c) Laparoscopic view of a right-sided Morgagni defect; A $5 \times 6-\mathrm{cm}$ size defect was found after the liver and colon were pulled out into the abdomen; (d) Laparoscopic view of the right lower portion of the pleural cavity through the hernia sac, revealing strangulated colon-induced purulent fluid with pus. 
barrier of the pericardial sac on the sternocostal trigon. MHs usually constitute only the omentum in infants and children, but with time, the defect enlarges until the abdominal organs herniate through. Pregnancy, trauma, obesity, chronic constipation, and chronic cough are common predisposing conditions contributing to the development of $\mathrm{MH}$. Exercise and other types of exertion may also result in symptoms. ${ }^{[4]}$ Symptomatic patients frequently complain of abdominal or chest pain and respiratory distress. Acute abdominal symptoms because of intestinal obstruction and strangulation are rarely observed, as seen in our patient. In cases of $\mathrm{MH}$, the great omentum and transverse colon are likely to herniate into the thoracic space. However, the stomach, small bowel, and liver also may be found within the hernia sac. Because the herniated organs are usually covered with the hernia sac (the parietal peritoneum), patients usually do not exhibit any symptoms. A strangulated $\mathrm{MH}$ with synchronous prolapse of the liver and transverse colon has been rarely reported in the literature.

Diagnosis of $\mathrm{MH}$ can be confirmed radiographically. Generally, on lateral radiography, a mass containing solid areas or fluid levels is observed at the cardiophrenic angle in the retrosternal space. However, diagnosis can be particularly challenging when the only radiographic finding is an anterior cardiophrenic angle abnormality with no evidence of bowel gas patterns in the chest. Contrast enema examination may also be useful, but CT is the best imaging method for demonstrating omental fatty tissue and intestinal air out of their localization. Magnetic resonance imaging is also considered to be a useful noninvasive modality for evaluating lower anterior mediastinal masses demonstrating fat density on $\mathrm{CT}^{[5]}$

Surgery provides definitive management for patients with an $\mathrm{MH}$. However, because the prevalence of $\mathrm{MH}$ has not been reported, it is impossible to compare operative and nonoperative management outcomes. Hence, the actual benefit of surgery remains unknown. However, several authors have opined that surgery is the most common treatment for both symptomatic and asymptomatic cases to prevent possible enlargement of the hernia sac and complications of strangulation. ${ }^{[6]}$ Primary repair can be performed via several methods and approaches, including thoracoscopic, laparoscopic, both thoracoscopic and laparoscopic, open transthoracic and abdominal. The primary advantage of the thoracic approach is that it provides easier dissection of the hernia sac off the mediastinal and pleural structures. The abdominal approach facilitates easier reduction of the hernia contents, evaluation of the contralateral diaphragm for additional defects, and concomitant evaluation and repair of other intra-abdominal pathology. Laparotomy is appropriate for management of symptomatic adult patients with a $\mathrm{MH}$, particularly those with findings of intestinal strangulation.

In conclusion, when confronted with assessing patients with respiratory distress and with symptoms suggestive of gastrointestinal obstruction, $\mathrm{MH}$ should be included in the differential diagnosis. Post-surgical recurrence rate of $\mathrm{MH}$ is very low and results area excellent. Thus, it should be borne in mind that surgical repair will prevent complications even in asymptomatic cases.

\section{Acknowledgements: This paper was supported by Wonkwang University in 2018.}

Conflict of interest: None declared.

\section{REFERENCES}

1. Bhasin DK, Nagi B, Gupta NM, Singh K. Chronic intermittent gastric volvulus within the foramen of Morgagni. Am J Gastroenterol 1989;84:1106-8.

2. Horton JD, Hofmann LJ, Hetz SP. Presentation and management of Morgagni hernias in adults: a review of 298 cases. Surg Endosc 2008;22:1413-20. [CrossRef]

3. Collie DA, Turnbull CM, Shaw TRD, Price WH. Case report: MRI appearances of left sided Morgagni hernia containing liver. Br J Radiol 1996;69:278-80. [CrossRef]

4. Lev-Chelouche D, Ravid A, Michowitz M, Klausner JM, Kluger Y. Morgagni hernia: unique presentations in elderly patients. J Clin Gastroenterol 1999;28:81-2. [CrossRef]

5. Kamiya N, Yokoi K, Miyazawa N, Hishinuma S, Ogata Y, Katayama N. Morgagni hernia diagnosed by MRI. Surg Today 1996;26:446-8.

6. Meredith K, Allen J, Richardson JD, Bergamini TM. Foramen of Morgagni hernia: surgical consideration. J Ky Med Assoc 2000;98:286-8.

\title{
OLGU SUNUMU - ÖZET
}

\section{Bir yetişkinde strangüle Morgagni hernisi: Karaciğer ve enine kolonun eş zamanlı prolapsusu}

\author{
Dr. Seok Youn Lee, ${ }^{1}$ Dr. Jung Nam Kwon, ${ }^{1}$ Dr. Yong Sung Kim, ${ }^{2}$ Dr. Keun Young Kim ${ }^{3}$ \\ ${ }^{1}$ Wonkwang Üniversitesi Sanbon Hastanesi, Wonkwang Üniversitesi Tıp Fakültesi, Cerrahi Bölümü, Gunpo-Kore \\ ${ }^{2}$ Tongkwang Üniversitesi Sanbon Hastanesi, Wonkwang Üniversitesi Tıp Fakültesi, İç Hastalıkları Anabilim Dalı, Gunpo-Kore \\ ${ }^{3}$ Wonkwang Üniversitesi Hastanesi, Wonkwang Üniversitesi Tıp Fakültesi, Cerrahi Bölümü, Iksan-Kore
}

Morgagni hernisi $(\mathrm{MH})$ kasın kostal ve sternal bölümleri arasında diyafragmanın ön yüzünde çok seyrek saptanan doğuştan bir defekttir. En sık görülen defekt doğuştan diyafragma hernisi \%90 oranında Bochdalek tipidir. MH'leri tüm diyafragmatik hernilerin aşağı yukarı \%90'ını oluşturur. MH'lerin çoğu çocuklarda bulunur ve onarılır, ancak \%5’i erişkinlerdedir. Burada, enkansere ve strangüle MH ile eş zamanlı karaciğer ve enine kolon düşüklüğü olan ve karın ağrısı ve intestinal obstrüksiyon semptomlarıyla hastanemize kabul edilmiş 77 yaşındaki bir erkek hastayı sunuyoruz.

Anahtar sözcükler: Eş zamanlı; Morgagni hernisi; yetişkin.

Ulus Travma Acil Cerrahi Derg 2018;24(4):376-378 doi: 10.5505/tjtes.2017.99045 